\section{A transversalidade da ética na Pós-Graduação em Serviço Social}

Carvalho Neto, Cacildo T. de.

Universidade Federal do Triângulo Mineiro; E-mail: cacildoneto37@gmail.com

\section{Engler, Helen B. Raiz}

Faculdade de Ciências Humanas e Sociais, Unesp Campus Franca/SP

PALAVRAS-CHAVE: Ética; pós-graduação; Serviço Social; transversalidade.

Introdução. $\mathrm{O}$ presente trabalho é resultado da tese de doutorado apresentada ao Programa de Pós-Graduação em Serviço Social (PPPGSS) da Faculdade de Ciências Humanas e Sociais, Unesp Campus Franca/SP, intitulada "A transversalidade da ética na Pós-Graduação em Serviço Social", em março de 2018. O objeto de estudo: a ética na pesquisa com seres humanos nas Ciências Humanas e Sociais. Objetivo geral: compreender o debate da ética na pesquisa com seres humanos nas Ciências Humanas e Sociais a partir do estudo de caso do PPPGSS, considerando a ética enquanto tema transversal no processo de formação strito sensu. Método. Método dialético. De natureza qualitativa; tipos de pesquisa bibliográfica, documental e de campo. O cenário de pesquisa foi o PPPGSS. O universo de pesquisa formado de 13 docentes do Programa, de forma intencional foram convidados 4 sujeitos; utilizou-se para a apreensão dos dados a entrevista semiestruturada; e 45 doutorandos, para apreensão dos dados utilizou-se de questionário eletrônico. Foram analisados os portais Plataforma Geocapes, Sucupira, Coleta Capes e Unesp, a fim de identificar o debate da ética na área de concentração, linhas de pesquisa, disciplinas (títulos e ementas com expressões ética e ou ético-político) e dissertações/teses (títulos com expressões ética e ou ético-político). Resultados. No item disciplinas constam o total de 52 disciplinas no período de 2012 a 2017, para Mestrado e Doutorado, dessas, apenas 7 contemplaram os critérios. No item dissertações e teses, constam a produção de 312 dissertações e 150 teses, dessas, 11 dissertações e 6 teses contemplaram os critérios elencados. Da apreensão dos sujeitos diante a transversalidade da ética no cenário pesquisado: dos 4 docentes, 3 não apreendem o debate da ética e ou ética na pesquisa no processo de formação da PósGraduação; dos 45 discentes doutorandos, apenas 13 responderam o questionário eletrônico; desses, 6 participantes não apreendem a transversalidade da ética e 7 participantes relataram apreender o debate da ética no processo de formação pós-graduada relacionando ao debate da ética profissional em Serviço Social. Conclusões. Partindo das considerações dos sujeitos e por ser parte desse universo, compreendemos que o Programa de Pós-Graduação em Serviço Social da FCHS possibilita a discussão da ética, mas é necessário retomar em sua grade uma disciplina com a finalidade de fazer os discentes estudarem e refletirem criticamente sobre a ética e a ética na pesquisa. Outras ações são relevantes, como a parceria e incentivo para o desenvolvimento de eventos que tenham essa temática em sua centralidade. Aqui cabe a parceria com o Comitê de Ética em Pesquisa dessa Faculdade, o qual vem desenvolvendo algumas atividades de cunho socioeducativo.

\section{REFERÊNCIAS}

[1]JONAS, H. O princípio responsabilidade: ensaio de uma ética para a civilização tecnológica. Rio de Janeiro: Contraponto: Ed. PUC-Rio, 2006.

[2]OLIVEIRA, M.A. Ética e racionalidade moderna. São Paulo: Loyola, 1993.

[3]SANTOS, B. S. Um discurso sobre as ciências. São Paulo: Cortez, 2010. 